\title{
Panatacara Text of Sanggar Pasinaon Pambiwara Keraton Surakarta as a Nation Character Builder in Language Politeness
}

\author{
Sidhiq Hidayatulloh ${ }^{1, *}$, Sahid Teguh Widodo ${ }^{2}$, Kundharu Saddhono ${ }^{3}$ \\ ${ }^{1,3}$ Universitas Sebelas Maret, Surakarta, Indonesia \\ ${ }^{2}$ University Centre of Excellencece Javanology for Javanese Tradition, Universitas Sebelas Maret, Surakarta, \\ Indonesia \\ "Corresponding author.Email: sidhighidayatulloh95@gmail.com
}

\begin{abstract}
Panatacara text functions as a means for a presenter to coordinate an event so that the event runs following the order. The text uses Krama Inggil which has the highest level of politeness. Panatacara text has been learnt from generation to generation through the Sanggar Pasinaon Pambiwara Keraton Surakarta. This research is qualitative-descriptive research with a content analysis approach. The sources of data are books and texts belonging to Sanggar Pasinaon Pambiwara Keraton Surakarta Hadiningrat. The research used a single fixed strategy in which the research focus has been determined based on the aims and interests of the researchers before going into the field of study. This research aims to find the values of the Panatacara text of Sanggar Pasinaon Pambiwara Keraton Surakarta as a nation character builder in language politeness. The result shows that there are seven-character education values generated from Panatacara text which can be implemented in everyday life, they are the value of honesty, the value of hard work, the value of independence, the value of creativity, the value of the national spirit, the value of friendship and communication, and the value of social awareness.
\end{abstract}

Keywords: Character Builder, Keraton Surakarta, Language Politeness, Panatacara Text

\section{INTRODUCTION}

Panatacara text functions as a means for the presenter in mixing, matching, and coordinating the course of an event so that the event runs in accordance with the existing order. Panatacara text uses the subtle Javanese language which is commonly referred to as Krama Inggil. Krama Inggil has the value of the highest level of refinement and politeness and is meaningfully encoded. Thus, Panatacara text needs to be studied in the academic realm and this study is expected to have a positive impact on society.

The Panatacara text which is still being studied consistently to date is the Panatacara text used in the Surakarta Palace, Central Java. The Panatacara text has been reviewed and studied from generation to generation through the Sanggar Pasinaon Pambiwara Keraton Surakarta (Studio for training courses for presenters or event organizers in
Javanese). This studio is very concerned about fostering and educating the public to be willing and able to learn various kinds of Panatacara texts from the Surakarta Palace. Thus, the regeneration will not be lost and the nation's noble culture will continue to be preserved in the midst of today's modernization. The studio has a focus on organizing the Pambiwara (Master of Ceremony) course. Initially, the course was held at Sasana Marcukunda founded by the palace to give a platform for people who want to learn Krama Inggil in more detail. The process of learning Krama Inggil in this studio is different from the one outside the Kraton. The Krama Inggil taught in this studio comes directly from the palace with all distinct intonations and its application through speech because in general this language is used for people who learn to give speeches in Javanese for certain purposes.

In addition, Sanggar Pasinaon Pambiwara Keraton Surakarta also has the vision to maintain a 
traditional culture amidst the growing external culture. At that time, the King of the Kasunanan Palace, PB XII gave orders to Raden Mas Haryo Yosodipuro to develop and preserve materials for pambiwara. The Panatacara texts in the Surakarta Palace contain various aesthetic and educational values which are useful for the nation's future generations. Unfortunately, the younger generation does not care enough and is not even aware of the various forms of Panatacara texts which are full of cultural and ethical values. The younger generation prefers to learn things which are modern and instantaneous in the current era of globalization, so they seem indifferent to the various cultural products around them. If it is studied in depth, it will have a positive impact on society. By knowing and studying various kinds of cultural products, they will be better acquainted with the identity of their nation, more humanist in society, and wiser in actualizing themselves. Also, the value of character education for each individual can be maximized because it is oriented towards noble cultural treasures. This is because Javanese culture is a system serving as a guideline for Javanese people in their behaviour and attitudes and Javanese culture has local wisdom serving as a strong driver in the life of Javanese people (Saddhono \& Pramestuti, 2018).

A character is defined as unique and good values (knowing the value of goodness, willing to do good, and actually have a good life) which are embedded in oneself and are manifested in behaviour. Character coherently emanates from the results of thought, feeling and intention, as well as physical acts of a person or group of people (Mulyasa, 2014). Character does not always reflect good behaviour because everyone has different perspectives and life habits. It takes a long time to build character and must be carried out continuously. Character education must be sustainable in order to prepare a quality generation of the nation. Character education is about how to instill habits about good things in life so that someone has awareness, sensitivity, understanding, care, and commitment to apply virtue in everyday life.

Efforts can be made to conduct education about culture and internalization of the noble values of Javanese culture through teaching and learning activities. Teaching and learning activities are intended to maximize the potential existing in the nation's future generations to be continuously explored, utilized and developed in order to become quality human beings so as to create a dignified future generation. Education is understood as a process of cultural internalization into a person and society so that it makes people and society adapt (Muslich, 2011). This is also in line with the realm of character education for the nation's children consisting of three main values, namely transfer of knowledge, transfer of culture, and transfer of value which must be learned (Nugroho, 2016). Thus, culture-based teaching and learning activities can be used as a means of inheriting culture and at the same time providing comprehensive education. One of them is by utilizing the Panatacara text as teaching material in Javanese Language Subjects.

Nowadays, the enthusiasm of students to learn and appreciate Javanese language is getting low. Javanese language is still considered boring and difficult to understand, so they tend not to be enthusiastic about learning it. This kind of phenomenon is of particular concern to researchers to urge and invite the younger generation to want to learn and develop Javanese texts, especially the Panatacara text in the Surakarta Palace. In addition to the cultural aspects in general, the text contains the values of noble character education which can benefit students so that the researchers consider that the Panatacara text in the Surakarta Palace is suitable as teaching material for Javanese Language Subjects at the Senior High School (SMA) level.

The appropriateness of the Panatacara text as teaching material for Javanese Language Subjects is also inseparable from the existence of the concept of values and sublime values in it. As a case of Javanese literature, the Panatacara text is a type of piwulang literary work because it contains life lessons for humans. In the Panatacara text, a good lesson is illustrated because it is able to provide messages, and guidelines for anyone who learns it. Sastra ingkang sumebar wonten bebrayan pranyata ngemot pitutur luhur lan piwulang kautaman tumraping gesang bebrayan, supados manungsa tansah emut lan nglenggana bilih gesang menika naming mampir ngombe, pramila kedah waspada lan tansah tumindak utama, anggayuh manungsa ingkang sampurna tansah asih tresna dhumateng sesama (Sutardjo, 2008). 'Literatures developing in social life contain good teachings and the glory of social life. They are purposed for humans to always remember and accept that life in this world is just like a brief transit, therefore they must be vigilant, introspective and always behave well, to be perfect human being and always have a sense of affection for others'

\section{MATERIALS AND METHODS}

This research is qualitative-descriptive research with a content analysis approach, while the sources of data are books and texts belonging to Sanggar Pasinaon Pambiwara Keraton Surakarta Hadiningrat. In this research, there are no specific 
limitations regarding the place of research. This research is mostly carried out in libraries and field research to obtain materials as sources of data.

Based on the problems posed in this research, the type of this research is descriptive-qualitative. This qualitative research is based on the sources of data; books and texts belonging to the Sanggar Pasinaon Pambiwara Keraton Surakarta Hadiningrat. The research strategy used in this research is a single fixed strategy. The single fixed strategy is qualitativedescriptive research in which the research focus has been determined based on the aims and interests of the researchers before going into the field of study (Wibowo, et al., 2019). The focus of this research is the Panatacara text of Sanggar Pasinaon Pambiwara Keraton Surakarta as a nation character builder.

\section{FINDINGS AND DISCUSSION}

Based on the results of document analysis and data identification, it is known as follows:

\subsection{Panatacara Text of Sanggar Pasinaon Pambiwara Sanggar Keraton as a Nation Character Builder}

\subsubsection{Teks Panatacara Gaya Sanggar Pasinaon Pambiwara Karaton Surakarta} Hadiningrat, Dening KPA. Winarnokusumo.

\section{Miwiti Mbikak Pahargyan}

\subsubsection{Hambuka lampahing Tatacara}

Assalamualaikum wr.wb.

Sih rahmating Gusti Ingkang Maha Asih mugi nunggil ing para tamu sekaliyan. Bapa Ibu, Para tamu kakung saha putri ingkang winengku ing karahayon. Keparengna pambiwara hangaturaken pratelan ringkes lampahing tatacara pahargyan ing siang/dalu punika. Dene minangka purwakaning tatacara, penganten putri mijil saking panti busana kalenggahaken ing palenggahan rinengga. Nuli bidhaling kang piniji hamethuk penganten Priya. Praptaning penganten Priya dalah pangiring ing wisma pahargyan nuli katindakaken tatacara tatacara pasrah tinampi. Purnaning pasrah tinampi kalajengaken tatacara panggih. Sesampunipun penganten sekaliyan lenggah satata nuli katindakaken tatacara krobongan. Salajengipun rawuhing besan sapandherek. Sesampunipun lenggah satata kalajengaken tatacara pangabektinipun penganten sakaliyan. Pasugatan lelangen beksan kapisan katur. Kalajengaken atur pambageharja, kasambet tatacara kirab, pasugatan beksan angka kalih katur. Tumuli penganten sakaliyan wangsul mring palenggahan sakawit. Wursita wara nuli kaparingaken dhateng penganten sekaliyan. Dene minangka pungkasaning tatacara penganten sekaliyan jengkar saking palenggahan sumadya jumeneng ing sangajenging pandhapi pahargyan. Mekaten lampahing tatacara ing siyang/dalu punika, mugi rahayu sarwi sembada kang sinedya.

\subsubsection{Penganten Putri Mijil}

Para tamu kakung putri ingkang winengku ing suka basuki. Pahargyan ing siyang/dalu punika tumuli badhe pinurwakan. Keparenga Ibu ............. saha Ibu ............... hanganthi penganten putri saking sasana busana kalenggahaken ing palenggahan rinengga kanthi kairing ungeling Ketawang Puspawarna laras Sl.Many. Sumangga.

\subsubsection{Methuk Penganten Priya}

Penganten putri sampun kepareng lenggah, keparenga Bp..... sarta Bp. ..... Nuli bidhal hamethuk penganten Priya ing palereman, kadherekaken ungeling Lancaran. Udan Mas Pl.Br. Sumangga.

\subsubsection{Penganten Priya Rawuh}

Para tamu kakung putri, sasmita ingkang tinampi, penganten Priya kepareng rawuh, ingkang punika keparenga Bp. ........... samekta hangacarani, praptaning penganten Priya kabiwadha ungeling Ldr. Wilujeng Pl.Br. Sumangga.

\subsubsection{Pasrah Tinampi}

Hingkang kepareng badhe hamasrahaken penganten Priya, Bp. ..... dene ingkang kepareng hanampi Bp....... sinumbul Bp. ...... Miwah Bp. ...... Sasampunipun samekta nuli kasumanggakaken Bp. ........ kepareng hamasrahaken, sumangga. Keparenga Bp. .............. tumuli hananggapi, sumangga.

\subsubsection{Panggih}

Sesampunipun katindakaken tatacara pasrah tinampi, penganten sekaliyan nuli badhe kapanggihaken. Keparengna Bp. .......... sarta Bp. .............. hanganthi penganten Priya, dene Ibu ....... Sarta Ibu ......... hanganthi penganten putri, ingkang kasuwun hanyepuhi panggih penganten sekaliyan Ibu ....... Dene ingkang hanyamektakaken ubarampening tatacara panggih Ibu ......miwah Ibu ......... Sesampunipun penganten sekaliyan panggih, Ibu...... Kepareng hanyingkebaken sindur dhateng ingkang putra pun penganten sekaliyan. Panggihing penganten kinurmatan ungeling gansa Kodhok Ngorek kalajengaken Ketawang Larasmaya Pl.Br. kasumanggakaken keparengipun para tamu anggenipun paring puji pangestu dhateng penganten sekaliyan. Manawi wonten keparengipun kula dherekaken jumeneng, sumangga. 


\subsubsection{Krobongan}

Hawit saking berkah rahmating Gusti sarta puji pangestunipun para tamu, penganten sampun kepareng panggih kanthi wilujeng. Sesampunipun satata ing palenggahan rinengga, nuli badhe katindakaken tatacara Krobongan, Bobot timbang, Kacar-kucur, lan sapanunggalanipun. Dene kalampahanipun kasumanggakaken ing Ibu ....... Miwah Ib........ kanthi binarung ungeling $L d r$. Sriwidada Pl.Br. Sumangga.

\subsubsection{Sungkeman sesampunipun besan rawuh}

Para tamu kakung saha putri, hatur uninga bilih Besan Bp. ........... sekaliyan sapandherek kepareng badhe rawuh mertuwi. Keparenga $\mathrm{Bp}$............. sekaliyan hamarepegi lajeng kadherekaken pinanggya kaliyan ingkang hamengku karya, kanthi kairing ungeling Ldr. Tirtakencana Pl.Nem. Sumangga.

\section{Sungkeman:}

Kados sampun kepareng satata lenggah prayogi Bp. .......... Sekaliyan. Salajengipun tumapaking tatacara sungkeman kasumanggakaken Ibu.......... Dalah Ibu ............ Keparenga hamranata lampahipun. Dene Bp. Keparenga hanglolos wangkinganipun Penganten Priya. Tumapaking tatacara Sungkeman binarung ungeling Ldr. Mugi Rahayu. Sl.Mny, Sumangga.

\subsubsection{Lelangen Beksan}

Para tamu kakung putri ingkang winengku ing pakurmatan. Bp. ......... sekaliyan badhe hangaturaken pasugatan beksan, dene beksan kapisan badhe katur Gambyong Pareanom, ingkang badhe katindakaken

dening:

\subsubsection{Atur Pambageharja}

Para tamu kakung putri ingkang satuhu luhuring budi. Mugi pasugatan beksan ingkang sampun katur sageda akarya panglipur penggalih panjenengan sekaliyan. Hing salajengipun Bp. .......... Kekalih badhe matur ing ngarsa panjenengan, dene atur Bp ...... Kekalih badhe kalantaraken dening $\mathrm{Bp}$......... Ingkang jumenengipun kasumbul dening $B p \quad$...... Miwah Bp. .......... salebetipun atur pambageharja katindakaken, penganten sekaliyan kepareng jumeneng wonten sangajenging palenggahan kanthi kaapit dening Bapa Ibu ingkang kapratitisaken dening Ibu ..............miwah Ibu ............, sumangga.

\subsubsection{Kirab}

Purnaning atur pambageharja, penganten sekaliyan kepareng badhe kajengkaraken saking palenggahan saperlu badhe kakirabaken. Keparenga
Bapa/ Ibu .......... hamranata lampah sarta kirab. Dene paraga kirab ingkang sampun kapacak: Suba manggalaning lampah ........., Satriya kembar minangka panyumbul Bgs. .......sarta Bgs. ........, Patah sakembaran $R r$. ...... Miwah $R r$. ....... Pangarih Ibu......miwah Ibu ......... Putri Dhomas ........, ......., ...., ......, Para kadang pangombyong, Bp/Ibu ......., Bp/Ibu ......, Bp/Ibu ....... Dene minangka pethiting lampah besan miwah ingkang hamengku karya sekaliyan. Kirabing penganten kairing ungeling Ketawang Langengita Sri Narendra Pl.Br. Sumangga.

\subsubsection{Kirab Wangsul}

Para tamu kakung putri, penganten sekaliyan hanggenipun santun ageman sampun cekap, badhe wangsul dhateng palenggahan sekawit, dene para paraga sami kados kirab ing ngajeng, wangsuling penganten kairing ungeling Ketawang Subakastawa Sl.9. Sumangga.

\subsubsection{Ular-ular (Wursita Wara)}

Para tamu kakung saha putri ingkang winantu ing karahayon. Sesasmpunipun penganten sakaliyan satata lenggah, kepareng badhe hanampi wursita wara ingkang badhe kaparingaken dening Bp.................. .

\subsubsection{Purnaning Pahargyan}

Para tamu kakung putri ingkang winantu ing suka basuki. Purwa, madya, wasana, katiti sampun prayogi samudayaning tatacara pahargyan sampun kalampahan kanthi wilujeng. Ingkang punika keparenga Bp. ........ekaliyan hanjengkaraken penganten sekaliyan, dene $B p$. ...... sekaliyan keparenga hangacarani jengkaripun Bp.......... Sekaliyan miwah besan sekaliyan. Kepareng sami samekta jumeneng wonten sangajenging pandhapi pahargyan saprelu hatangkep asta. Gendhing Ayakayakan kalajengaken Ldr. Tedhak Saking Pl.Br. suka pratandha paripurnaning pahargyan ing siyang/dalu punika. Dhumateng para paraga ingkang kapiji ing karya kula sumanggakaken.

\subsubsection{Panutuping Pambiwara}

Para tamu kakung putri ingkang satuhu luhuring budi. Pambiwara hanglenggana taksih kathah kuciwa anggenipun hangaturaken pratelaning lampah, Pramila mugi keparenga para tamu paring lumbering samodra pangaksama. Hing wasana panutuping atur, kula hangaturaken wilujeng konduripun sadaya para tamu kulisa ing rubeda. Nuwun. Wassalamualaikum $w r . w b$. 


\subsubsection{Panatacara Text of Sanggar Pasinaon Pambiwara Sanggar Keraton by KPA. Winarnokusumo.}

Starting the Opening of the Event

\subsubsection{Opening the event sequence}

Assalamualaikum wr.wb.

May God's goodness and mercy follow you today.

Ladies and gentlemen, let me read the rundown of the wedding reception today/tonight. To start it, the bride will walk into the venue to sit on the bride seat. Then, the assigned person leaves to pick up the groom. After the arrival of the groom and family at the wedding venue, the event continues with the handover ceremony of the bride and groom. Then, the procedure of panggih (the traditional ceremony of the meeting of the groom and bride) is conducted. After the bride and groom sit on the wedding seat, the krobongan ceremony is conducted. Next, the arrival of the extended family and parents of the groom (besan sapangombyong). After the couple sits, the next procedure is conducted as a form of devotion from the bride and groom to their parents. Then, traditional dance is going to be the first performed for entertainment, followed by delivering pambageharjo (welcoming speech to the guests from family representatives), continued by the main wedding ceremony, then the second dance for entertainment is performed. Next, the bride and groom return to the seat. After that, advice for the bride and groom in navigating the married life. Lastly, the bride and groom walk towards the exit of the venue to shake hands with the guests. That is the rundown of the wedding reception, we hope you all safe and happy here.

\subsubsection{The appearance of the bride}

Ladies and gentlemen, the event begins. Dear Mrs. ... and Mrs. ..., please walk along with the bride to the wedding seat. The process will be accompanied by the music of Ketawang Puspawarna laras Sl. Many. The floor is yours.

\subsubsection{The groom's pick up}

After the bride sits on the wedding seat, Mr. ... and $\mathrm{Mr}$.... are welcome to receive the arrival of the groom, accompanied by the music of Lancaran. Udan Mas Pl.Br. Sumangga.

\subsubsection{The appearance of the groom}

Ladies and gentlemen, we have got a sign that the groom has come. For that, dear Mr. ... please, be prepared to receive the groom's arrival, and the groom's arrival will be accompanied by the music of $\mathrm{Ldr}$. Wilujeng $\mathrm{Pl}$. Br. Time is yours.

\subsubsection{Handover Ceremony}

The person who is in charge of handing over (pasrah) the groom is Mr. ... who will be accompanied by Mr. ... and Mr. ... . Please, be prepared. Dear Mr. ..., you are welcome to accept.

\subsubsection{Panggih (the meeting of the bride and groom)}

After the handover is carried out, the panggih ceremony is held. Dear Mr. ... and Mr. ...., please accompany the groom, and Dear Mrs. ... and Mrs. ..., please accompany the bride. Mrs. ..., please organize and lead the course of panggih ceremony, to Mrs. ... and Mrs. ..., please, prepare the equipment used for the ceremony. After the ceremony is done, we will see Mrs... apply sindur to the bride and groom. This ceremony is accompanied by the song of Kodhok Ngorek, followed by the music of Ketawang Larasmaya pl.br. All the guests are welcome to stand up and send prayers and blessings to the couple.

\subsubsection{Krobongan}

With God's blessings and grace as well as the prayers and blessings from the guests, the bride and groom have carried out the panggih ceremony smoothly. After they sit on the wedding seat, the krobongan ceremony, bobot timbang, kucar-kucur, and so on will be carried out. To organize the course of the traditional ceremony, please welcome Mrs. ... and Mrs. .... The ceremonies will be accompanied by the music of Ldr. Sriwidada Pl.Br.

\subsubsection{Sungkeman}

Ladies and gentlemen, Mr. and Mrs. ... and the whole family have come. To Mr. and Mrs. ... Please welcome the arrival of the family-in-laws, then escort them to the reception area which has been provided by the bride's parents accompanied by the music of $L d r$. Tirtakencana Pl. Nem. Sumangga.

\section{Sungkeman:}

After everyone has put themselves in their respective places, Mr. ... and Mrs. ... please organize the course of the sungkem event. To Mrs. ... and Mr. ... feel free to hanglolos duwung or take off the keris. The Sungkeman ceremony is accompanied by the music of $L d r$. Mugi Rahayu. Sl.Mny. 


\subsubsection{Lelangen Beksan (Dance for entertainment)}

Ladies and gentlemen, Mr. and Mrs. ... will present you entertainment in the form of dance, the first entertainment will be the Gambyong Pareanom dance, which will be performed by:....,..,..., .., ...,...

\subsubsection{Delivering Pambageharja}

Ladies and gentlemen, I hope the dance performed just now can entertain us all. Next, Mr. and Mrs. ... will give some words in front of us, on behalf of Mr. and Mrs. ..., please welcome Mr. ... who will be accompanied by Mr. ... and Mr. ... . During the pambageharja arrangement, the bride and groom are asked to stand on the stage accompanied by the father and mother, it will be arranged by Mrs. ... and Mrs.... .

\subsubsection{Kirab}

After the pambageharja is done, the bride and groom can both stand up to prepare themselves for the kirab ceremony. $\mathrm{Mr} / \mathrm{Mrs}$... please organize the process of the kirab ceremony. The following will accompany: Suba manggalaning lampah ............ Satriya Kembar as accompanists, Mr. ... and Mr. ..., Patah Sakembaran, Ms. ... and Ms. ... . Pangarih, Mrs. ... and Mrs. ..., Putri Dhomas Ms. ..., ..., ..., ... . Para Kadang Pangombyong, Mr/Mrs. ..., ..., ..., ..., . The ceremony will be accompanied by the music of Ketawang Langengita Sri Narendra Pl.Br.

\subsubsection{Kirab Wangsul (Kirab for returning)}

Ladies and gentlemen, the bride and groom have finished changing their clothes, then they will return to the seat along with all their companions. The kirab wangsul ceremony will be accompanied by the music of Ketawang Subakastawa S1.9.

\subsubsection{Ular-ular (Advice)}

Ladies and gentlemen, after the bride and groom return to sit on the seat, please welcome Mr. ... to advise about the married life that the bride and groom will live in in the future.

\subsubsection{Purnaning Pahargyan (the end of the event)}

Ladies and gentlemen, the whole ceremonies have been carried out smoothly, so to Mr. and Mrs. ... please accompany the bride and groom to stand with their parents and in-laws, to walk and get ready to stand up to shake hands with all the guests. This will be accompanied by the music of ayak-ayakan and $L d r$. Tedhak Pl.Br. as a sign that today/tonight event has ended.

\subsubsection{Panutuping Pambiwara (Closing by MC)}

Ladies and gentlemen, as the master of ceremony, I realize that there are still some mistakes in organizing today/tonight event, for that, I apologize for everything that went wrong. Lastly, I would like to thank you for your presence, I hope you will be safe to the next place you will head to. Thank you. Wassalamualaikum wr.wb.

\subsection{The Value of Character Education in the Panatacara text of Sanggar Pasinaon Pambiwara Keraton Surakarta}

In the Panatacara text, there are several things related to the value of character education containing moral and educational values and is useful for life. From the analysis of the content contained in the Panatacara text of Sanggar Pasinaon Pambiwara Keraton Surakarta, the educational values are obtained as follows.

\subsubsection{The Value of Honesty}

The value of honesty contains behaviour and words which can be trusted and able to convince someone. This value is contained in the panutuping pambiwara.

\section{Panutuping Pambiwara :}

Para tamu kakung putri ingkang satuhu luhuring budi. Pambiwara hanglenggana taksih kathah kuciwa anggenipun hangaturaken pratelaning lampah, Pramila mugi keparenga para tamu paring lumbering samodra pangaksama.

Hing wasana panutuping atur, kula hangaturaken wilujeng konduripun sadaya para tamu kulisa ing rubeda. Nuwun.

\section{(KPA. Winarnokusumo)}

The above quote gives a very clear picture that a presenter must have an honest attitude, which is reflected in the closing text which always apologizes for any mistakes.

\subsubsection{The Value of Hard Work}

The value of hard work is also the material discussed in understanding the Panatacara text using Krama Inggil which is unfamiliar to students.

\subsubsection{The Value of Independence}

Independence of thinking and behaving is also conveyed in the Panatacara text that a Panatacara must practice frequently so that they are capable and skilled in every situation. 


\subsubsection{The Value of Creativity}

Educational and creative values are always related because educational values also go hand in hand with human creativity. The value of education will be more meaningful with the existence of human creativity in doing something or producing new ways or objects that can be used in applicative life. A Panatacara must have a creative attitude so that in its application to appearances at every event there are always new things or new words displayed to the people around them.

\subsubsection{The Value of National Spirit}

One of the values contained in studying the Panatacara text is the national spirit. By preserving and loving culture, it will strengthen the national spirit. Unity is the main ideal that must be realized so as to create a high national spirit in social life based on noble religious values.

\subsubsection{The Value of Friendship and Communication}

Panatacara text also provides educational value to be friendly and have good communication with others. Interaction and communication must be carried out in the community so that life becomes more lively and respects people with good behaviour, including in terms of language. The following is a quote explaining that communication is very much needed in society.

\section{Pasrah Tinampi}

Hingkang kepareng badhe hamasrahaken penganten Priya, Bp..... dene ingkang kepareng hanampi Bp. ...... sinumbul Bp. ...... Miwah Bp. ......... Sesampunipun samekta nuli kasumanggakaken Bp. ........... kepareng hamasrahaken, sumangga.

Keparenga Bp. ............... tumuli hananggapi, sumangga.

\section{(KPA. Winarnokusumo)}

A Panatacara must present good aspects of communication for those around them and be able to express their thoughts in good manners.

\subsubsection{The Value of Social Awareness}

Every individual who lives in society must interact with other people and carry out activities which are in line with the values of social awareness. Panatacara text also has social awareness values which can be adapted in everyday life.

\section{CONCLUSION}

The educational value in the Panatacara text of Sanggar Pasinaon Pambiwara Keraton Surakarta consists of seven-character education values which can be implemented in everyday life. People can learn and adopt these values from various events and situations built up in studying Panatacara texts. The value of education can be identified from the Panatacara text because it provides comprehensive and useful aspects of interaction, exemplary, and moral messages that can be implemented in life (Devilito, 2017). Therefore, the value of character education is a definite value that can be found in the Panatacara text, including the Panatacara text of Sanggar Pasinaon Pambiwara Keraton Surakarta. Some of the character education values contained in the Panatacara text of Sanggar Pasinaon Pambiwara Keraton Surakarta include the value of honesty, the value of hard work, the value of independence, the value of creativity, the value of the national spirit, the value of friendship and communication, and the value of social awareness.

\section{Pangkur \\ (Raden Mas Haryo Yosodipuro) \\ Lamun madeg pambiwara \\ Hawya kongsi tilar catur prakawis \\ Kang dhihin sugih kawruh \\ Pindho olah suwara \\ Kaping telu yaiku busana besus \\ Kaping papat subasita \\ Tatakrama nora keri}

\section{A person who stands as Pambiwara}

Must understand and implement four things;

First, rich in knowledge

Second, having a pleasant voice

Third, understanding the rules of dress

Fourth, concerns about the environment,

Having manners and attitude

In the Pangkur song, it is clear that the rule for being a Panatacara is full of noble moral values. In addition, a Panatacara must master or understand the Panatacara text. Panatacara text has very good character education values as a nation character builder, such as always being introspective, responsive to mistakes and caring for the surrounding environment, courtesy to others, which are useful as a nation character builder.

\section{REFERENCES}

[1] E.M. Clarke, E.A. Emerson, Design and synthesis of synchronization skeletons using branching time temporal logic, in: D. Kozen (Eds.), Workshop on Logics of Programs, 
Lecture Notes in Computer Science, vol. 131, Springer, Berlin, Heidelberg, 1981, pp. 52-71. DOI: https://doi.org/10.1007/BFb0025774

[2] J.P. Queille, J. Sifakis, Specification and verification of concurrent systems in CESAR, in: M. Dezani-Ciancaglini and U. Montanari (Eds.), Proceedings of the 5th International Symposium on Programming, Lecture Notes in Computer Science, vol. 137, Springer, Berlin, Heidelberg, 1982, pp. 337-351. DOI: https://doi.org/10.1007/3-540-11494-7_22

[3] C. Baier, J.P. Katoen, Principles of Model Checking, MIT Press, 2008.

[4] M. Kwiatkowska, G. Norman, D. Parker, Stochastic model checking, in: M. Bernardo, J. Hillston (Eds.), Proceedings of the Formal Methods for the Design of Computer, Communication and Software Systems: Performance Evaluation (SFM), Springer, Berlin, Heidelberg, 2007, pp. 220-270. DOI: https://doi.org/10.1007/978-3-540-72522-0_6

[5] V. Forejt, M. Kwiatkowska, G. Norman, D. Parker, Automated verification techniques for probabilistic systems, in: M. Bernardo, V. Issarny (Eds.), Proceedings of the Formal Methods for Eternal Networked Software Systems (SFM), Springer, Berlin, Heidelberg, 2011, pp. 53-113. DOI: https://doi.org/10.1007/978-3-642-21455-4_3

[6] G.D. Penna, B. Intrigila, I. Melatti, E. Tronci, M.V. Zilli, Bounded probabilistic model checking with the muralpha verifier, in: A.J. Hu, A.K. Martin (Eds.), Proceedings of the Formal Methods in Computer-Aided Design, Springer, Berlin, Heidelberg, 2004, pp. 214-229. DOI: https://doi.org/10.1007/978-3-540-30494-4_16

[7] E. Clarke, O. Grumberg, S. Jha, et al., Counterexample-guided abstraction refinement, in: E.A. Emerson, A.P. Sistla (Eds.), Computer Aided Verification, Springer, Berlin, Heidelberg, 2000, pp. 154-169. DOI: https://doi.org/10.1007/10722167_15

[8] H. Barringer, R. Kuiper, A. Pnueli, Now you may compose temporal logic specifications, in: Proceedings of the Sixteenth Annual ACM Symposium on the Theory of Computing (STOC), ACM, 1984, pp. 51-63. DOI: https://doi.org/10.1145/800057.808665
[9] A. Pnueli, In transition from global to modular temporal reasoning about programs, in: K.R. Apt (Ed.), Logics and Models of Concurrent Systems, Springer, Berlin, Heidelberg, 1984, pp. 123-144. DOI: https://doi.org/10.1007/978-3642-82453-1_5

[10] B. Meyer, Applying "Design by Contract", Computer 25(10) (1992) 40-51. DOI: https://doi.org/10.1109/2.161279

[11] S. Bensalem, M. Bogza, A. Legay, T.H. Nguyen, J. Sifakis, R. Yan, Incremental component-based construction and verification using invariants, in: Proceedings of the Conference on Formal Methods in Computer Aided Design (FMCAD), IEEE Press, Piscataway, NJ, 2010, pp. 257-256.

[12] H. Barringer, C.S. Pasareanu, D. Giannakopolou, Proof rules for automated compositional verification through learning, in Proc. of the 2nd International Workshop on Specification and Verification of Component Based Systems, 2003.

[13] M.G. Bobaru, C.S. Pasareanu, D. Giannakopoulou, Automated assume-guarantee reasoning by abstraction refinement, in: A. Gupta, S. Malik (Eds.), Proceedings of the Computer Aided Verification, Springer, Berlin, Heidelberg, 2008, pp. 135-148. DOI: https://doi.org/10.1007/978-3-540-70545-1_14

[14] A.H. Wibowo, D. Djatmika, M.N.S. Ali, N.A.M Salim, B. Mohamad. The Texture of Indonesian Story Texts in Teen Literature, International Journal of Innovation, Creativity and Change, 5(2), pp. 1021-1041, 2019 